\title{
FIRST RECORDS OF CHIMAERA OPALESCENS (HOLOCEPHALI: CHIMAERIFORMES: CHIMAERIDAE) FROM MADEIRA AND NORTH-WEST AFRICAN COAST
}

\author{
Mafalda FREITAS $^{1 *}$, Sofia VIEIRA², Luísa COSTA ${ }^{1}$, João DELGADO², Manuel BISCOITO ${ }^{1,3}$, \\ and José A. GONZÁLEZ ${ }^{4}$
}

${ }^{1}$ Funchal Marine Biology Station, Oceanic Observatory of Madeira (OOM) and Marine and Environmental Sciences Centre (MARE), Funchal, Madeira, Portugal

${ }^{2}$ Fisheries Research and Development Service, Regional Government of Madeira, Funchal, Madeira, Portugal

${ }^{3}$ Funchal Natural History Museum, Madeira, Portugal

${ }^{4}$ Applied Marine Ecology and Fisheries (EMAP), i8UNAT, University of Las Palmas de Gran Canaria, Canary Islands, Spain

Freitas M., Vieira S., Costa L., Delgado J., Biscoito M., González J.A. 2017. First records of Chimaera opalescens (Holocephali: Chimaeriformes: Chimaeridae) from Madeira and north-west African Coast. Acta Ichthyol. Piscat. 47 (1): 81-84.

\begin{abstract}
This study reports new findings of Chimaera opalescens Luchetti, Iglésias et Sellos, 2011, which represent new records of this fish from Madeira and Morocco. The specimens were caught at the depths between 800 and $1221 \mathrm{~m}$. Additional specimens deposited in the Natural History Museum of Funchal (MMF) were also studied as a comparative material and the results are reported herein. The new records of $C$. opalescens extend the previously known area of distribution of this fish further south.
\end{abstract}

Keywords: deep-sea fish, new record, Archipelago of Madeira, Morocco, NE Atlantic

According to Weigmann (2016) there are 40 valid species of chimaeras representing two genera, Chimaera Linnaeus, 1758 and Hydrolagus Gill, 1862. The separation of those two genera is based only on the presence or absence of a distinct anal fin (Didier and Séret 2002, Weigmann 2016).

The genus Chimaera includes 16 species (Weigmann 2016) two of which, Chimaera monstrosa Linnaeus, 1758 and Chimaera opalescens Luchetti, Iglésias et Sellos, 2011, are known from the northeast Atlantic Ocean (Luchetti et al. 2011, Weigmann 2016, Eschmeyer et al. 2017).

Chimaera opalescens can be distinguished from its congener by the following combination of characters: body colour beige to tan in adults and bronzy in juveniles, unpaired fins brown to purple, uniformly coloured or with pale or whitish edges, iris black, claspers tripartite divided for one third of their length, not extending beyond pelvic fins in adults, dorsal spine equal or shorter than first dorsal fin, ventral caudal lobe equal or deeper than dorsal caudal lobe and pectoral fins just reaching origin of pelvic-fin when laid backwards, in freshly caught adult specimens (Luchetti et al. 2011). Despite the distinct morphological differences, mainly in the claspers, dorsal spine and fins, it is still commonly misidentified as Chimaera monstrosa (see Luchetti et al. 2011, Vieira and Cunha 2014).

Chimaera opalescens was found within the depth range of 900-1975 $\mathrm{m}$ (Luchetti et al. 2011, Vieira and Cunha 2014, Weigmann 2016). Its geographic distribution extends from Greenland to the western slope of the British Isles and France, at latitudes between $48^{\circ}$ and $59^{\circ} \mathrm{N}$ (Møller et al. 2004, Luchetti et al. 2011, Holt et al. 2013), the Galicia Bank (Bañon et al. 2016), and south to the Gorringe Bank $\left(36^{\circ} 37.95^{\prime} \mathrm{N}, 11^{\circ} 02.25^{\prime} \mathrm{W}\right.$ ) (Vieira and Cunha 2014).

Chimaera opalescens, presented in this study, constitutes the first record of this fish from the Island of Madeira and northwest African coast, thus extending the southernmost limit of its distribution.

In this study a total of nine specimens of Chimaera opalescens from the Island of Madeira and from the northwest African coast were examined (Fig. 1). Six of them came from the black scabbardfish fishery in Madeira (800-1200 m of depth): MMF18538, $745 \mathrm{~mm}$ TL, male, 24/08/1961; MMF20455, 625+ mm TL, male, 23/06/1964;

* Correspondence: Mafalda Freitas, OOM - Estação de Biologia Marinha do Funchal and MARE - Centro de Ciências do Mar e do Ambiente, Cais do Carvão, 9000-107 Funchal, Madeira, Portugal,phone:(+351)291700360,e-mail:(MF)mafalda.freitas@cm-funchal.pt,(SV)sandravieira@gov-madeira.pt,(LC)luisa.costa@cm-funchal.pt, (JD)joaodelgado.sra@gov-madeira.pt, (MB) manuel.biscoito@cm-funchal.pt, (JAG)pepe.solea@ulpgc.es. 
MMF23185, 639+ mm TL, male, 03/1977; MMF23947, $863 \mathrm{~mm}$ TL, female, 12/02/1986; MMF 42362, $700 \mathrm{~mm}$ TL, female, 27/07/2012; MMF44359, $782 \mathrm{~mm}$ TL, male, $03 / 03 / 2015$. Three additional specimens came from the African coast: MMF37259, $775 \mathrm{~mm}$ TL, female, NWAfrican slope $\left(30.20^{\circ} \mathrm{N}, 10.24^{\circ} \mathrm{W}\right), 1221 \mathrm{~m}$ depth, 20/01/2006; MMF37260 (Fig. 2), $858 \mathrm{~mm}$ TL, male, NW African slope $\left(26.05^{\circ} \mathrm{N}, 15.27^{\circ} \mathrm{W}\right), 897 \mathrm{~m}$ depth, 23/01/2006; MMF38518, $117 \mathrm{~mm}$ TL, newborn, NW African slope $\left(26.18^{\circ} \mathrm{N}, 15.04^{\circ} \mathrm{W}\right), 840 \mathrm{~m}$ depth, 18/02/2006.

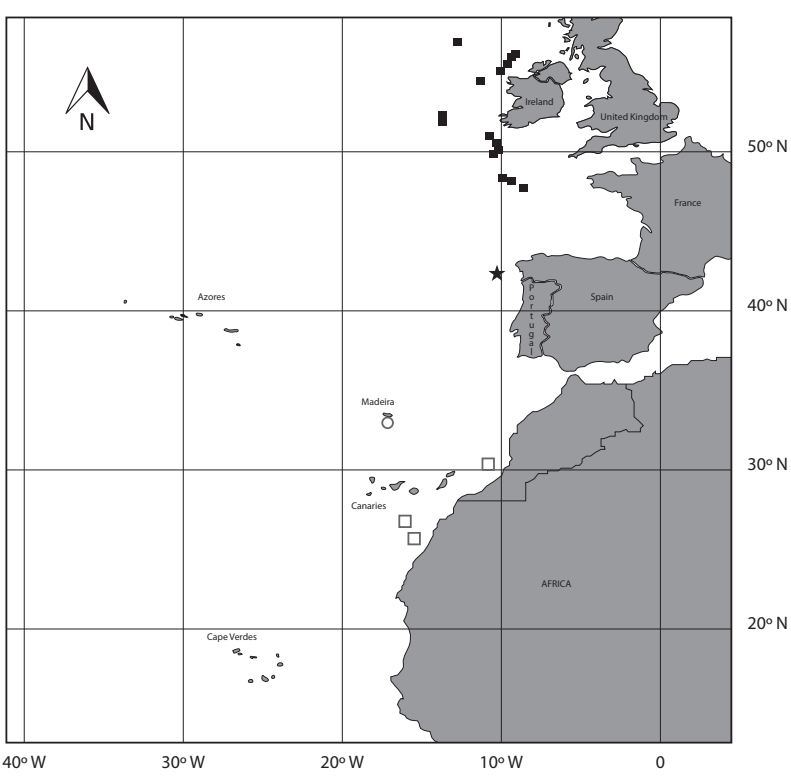

Fig. 1. Collection locations of Chimaera opalescens: 30 specimens from British Isles and France (Luchetti et al. 2011), $\star 4$ from Galicia bank (Bañon et al. 2016), and 8 from the presently reported study: $\bigcirc 6$ from the Island of Madeira and $\square 3$ from the Northwest African coast

The Madeiran specimens were caught as bycatch of the traditional black scabbardfish (Aphanopus carbo Lowe, 1839 and Aphanopus intermedius Parin, 1983) deep-sea fishery, four of which had been deposited in the collections of the Funchal Natural History Museum and originally identified as $C$. monstrosa.

The northwest African specimens were collected with bottom trawls in the framework of a Scientific Cooperation
Protocol between Spain and Morocco (González et al. 2014, González and Biscoito 2015).

All specimens were measured following Didier and Séret (2002) and Luchetti et al. (2011). Abbreviations: TL = total length, PCL = pre-caudal length, PD2 = pre-second dorsal fin length, PD1 = pre-first dorsal fin length, HDL = head length, DSA = dorsal spine length along anterior margin, $\mathrm{D} 1 \mathrm{~B}=$ first dorsal fin base length, IDS = inter-dorsal space, $\mathrm{D} 2 \mathrm{~B}=$ second dorsal fin base length, $\mathrm{CFI}=$ caudal-filament length, $\mathrm{P} 1 \mathrm{~A}=$ pectoral-fin anterior margin length, $\mathrm{P} 2 \mathrm{~A}=$ pelvic-fin anterior margin length, EYL = eye length, $\mathrm{EYH}=$ height, $\mathrm{CLT}=$ total length of clasper.

Two damaged specimens were not included in the morphological analysis. All voucher specimens were deposited in the collections of the Funchal Natural History Museum (MMF).

Our description of the newly found specimens is consistent with the description of Chimaera opalescens given by Luchetti et al. (2011) (Table 1).

In Fig. 3 the male sexual characters of one of the studied specimens are shown, in which the denticle arrangement in the frontal and prepelvic tenacula and the shape of the prepelvic tenaculum and claspers, are identical to the description given by Luchetti et al. (2011) for this species.

The presently reported record of Chimaera opalescens extends by 10 degrees to the South the previously known range of the species and also reduces the minimum depth $(800$ $\mathrm{m})$ for the species as compared to the previously published range of 900-1975 m (Weigmann 2016). The species was simply listed with no other details in a paper by Pajuelo et al. (2016) dealing with the assemblages of deep-sea fishes from off northwest Africa. Following the recommendations of Bello et al. (2014), the present account represents the first confirmed record of $C$. opalescens from NW Africa.

Before this study, only two species of the family Chimaeridae were known to occur in Madeira, Chimaera monstrosa (see Maul 1949) and Hydrolagus affinis (de Brito Capello, 1868) (see Freitas et al. 2011). While reexamining the MMF specimens, originally identified as $C$. monstrosa, we came to the conclusion that they were in fact Chimaera opalescens. Since we were not able to locate specimens of $C$. monstrosa from Madeira in museum collections and Maul's (1948) reference is older than the oldest specimen in MMF, the occurrence of C. monstrosa in Madeira remains dubious.

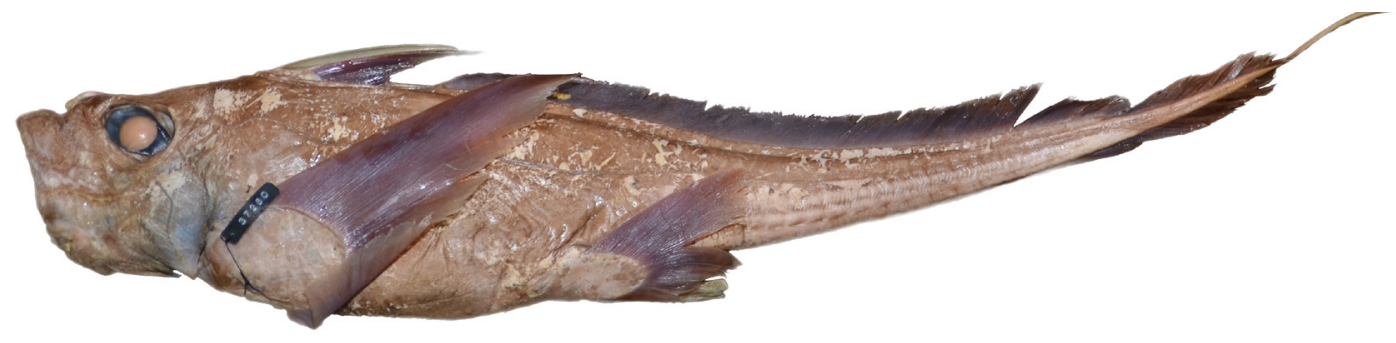

Fig. 2. Chimaera opalescens from NW African slope (MMF37260, $858 \mathrm{~mm}$ TL, male, $\left.26.05^{\circ} \mathrm{N}, 15.27^{\circ} \mathrm{W} ; 897 \mathrm{~m}\right)$ 
Table 1

Comparison between Chimaera opalescens from Madeira and NW Africa and species type material. See material and methods for the meaning of abbreviations

\begin{tabular}{lccccccc}
\hline & \multicolumn{3}{c}{ Madeira and NW Africa } & & \multicolumn{3}{c}{ British Isles and France } \\
\cline { 2 - 3 } \cline { 6 - 8 } Variable & Range [mm] & Range [\%PCL] & Mean & & Range [mm] & Range [\%LPC] & Mean \\
\hline TL & $745-863$ & $121.7-148.7$ & 135.6 & & $452-1098$ & $120.4-171.1$ & 147.6 \\
PCL & $526-703$ & 100.0 & 100.0 & $310-776$ & 100.0 & 100.0 \\
PD2 & $171-243$ & $29.0-37.2$ & 33.3 & $113-286$ & $35.5-39.1$ & 37.5 \\
PD1 & $102-152$ & $18.3-21.6$ & 20.0 & $67-157$ & $18.8-25.6$ & 21.5 \\
HDL & $97-133$ & $16.2-20.5$ & 18.5 & $69-146$ & $17.7-23.2$ & 19.7 \\
DSA & $80-104$ & $14.4-19.0$ & 16.4 & $53-132$ & $12.4-19.5$ & 17.1 \\
D1B & $42-67$ & $7.1-11.6$ & 9.5 & $40-84$ & $9.8-13.2$ & 11.4 \\
IDS & $21-52$ & $3.4-7.4$ & 4.9 & $4-55$ & $1.3-7.1$ & 4.7 \\
D2B & $299-378$ & $52.8-68.4$ & 58.2 & $193-494$ & $61.4-65.2$ & 62.9 \\
CFI & $140-207$ & $22.9-37.3$ & 28.3 & $18-235$ & $2.7-50.7$ & 22.3 \\
P1A & $127-181$ & $22.9-34.4$ & 27.3 & $92-205$ & $24.5-31.4$ & 27.6 \\
P2A & $73-99$ & $12.0-17.1$ & 14.2 & $46-120$ & $13.9-17.6$ & 15.2 \\
EYL & $26-40$ & $4.1-6.9$ & 5.6 & $27-51$ & $6.3-9.3$ & 7.9 \\
EYH & $16-29$ & $3.0-5.2$ & 3.9 & $17-34$ & $3.7-6.1$ & 4.8 \\
CLT & $51-82$ & $9.7-14.1$ & 11.7 & $68-73$ & $10.3-11.4$ & 18.0 \\
\hline
\end{tabular}

Material from Madeira and NW Africa (5 males, 2 females) represents the presently reported study; Material from British Isles and France (15 males, 15 females) represents data of Luchetti et al. 2011; TL = total length, PCL = pre-caudal length, PD2 = pre-second dorsal fin length, $\mathrm{PD} 1=$ pre-first dorsal fin length, $\mathrm{HDL}=$ head length, $\mathrm{DSA}=$ dorsal spine length along anterior margin, $\mathrm{D} 1 \mathrm{~B}=$ first dorsal fin base length, IDS = inter-dorsal space, $\mathrm{D} 2 \mathrm{~B}=$ second dorsal fin base length, $\mathrm{CFI}=$ caudal-filament length, $\mathrm{P} 1 \mathrm{~A}=$ pectoral-fin anterior margin length, $\mathrm{P} 2 \mathrm{~A}=$ pelvic-fin anterior margin length, $\mathrm{EYL}=$ eye length, $\mathrm{EYH}=$ height, $\mathrm{CLT}=$ total length of clasper.
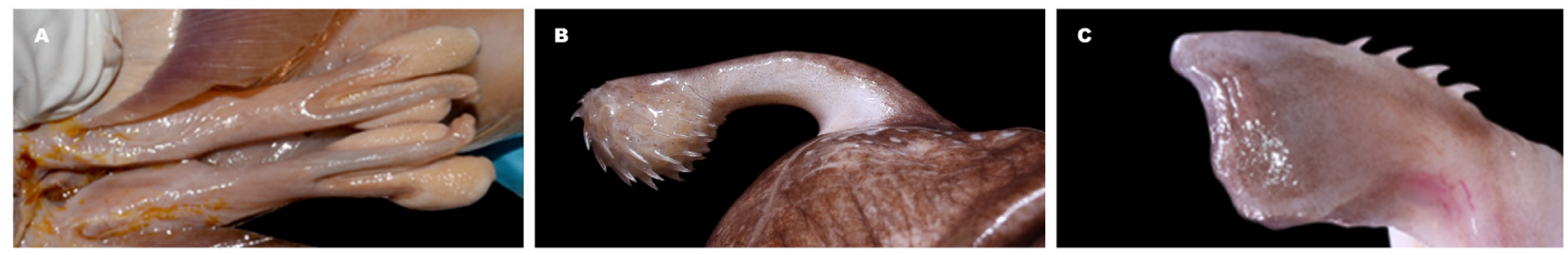

Fig. 3. Male sexual characters of Chimaera opalescens (MMF37260, $858 \mathrm{~mm} \mathrm{TL)}$ ) claspers (A), frontal tenaculum in dorsal view (B) and prepelvic tenaculum in ventral view $(\mathbf{C})$

\section{ACKNOWLEDGEMENTS}

The authors are indebted to the masters, crews and on-board scientific observers of the F/V Farruco, F/V Mar Rojo Dos, and F/V Varalonga for their cooperation in obtaining the specimens from NW Africa. This research was partially financed by the European Union, Spanish Ministry for Fisheries, and owners of the vessels involved. Some of the authors (MF and $\mathrm{MB}$ ) received support from Project M1420-01-0145-FEDER-000001project Observatório Oceânico da Madeira (OOM) and Fundação para a Ciência e Tecnologia (FCT), through the strategic project UID/MAR/04292/2013 granted to MARE. This is Contribution No. 4 of the SpanishMoroccan 2005-2006 deep-sea fishery campaigns off NW Africa. This is Contribution No. 34 of the Funchal Marine Biology Station.

\section{REFERENCES}

Bañon R., Arronte J.C., Rodriguez-Cabello C., Piñeiro C.-G., Punzon A., Serrano A. 2016. Commented checklist of marine fishes from the Galicia Bank seamount (NW Spain). Zootaxa 4067 (3): 293-333. DOI: 10.11646/zootaxa.4067.3.2

Bello G., Causse R., Lipej L., Dulčić J. 2014. A proposed best practice approach to overcome unverified and unverifiable "first records" in ichthyology. Cybium 38 (1): 9-14.

Didier D.A., Séret B. 2002. Chimaeroid fishes of New Caledonia with description of a new species of Hydrolagus (Chondrichthyes, Holocephali). Cybium 26 (3): 225-233.

Eschmeyer W.N., Fricke R., van der Laan R. (eds.) 2017. Catalog of fishes: Genera, species, references. California Academy of Sciences, San Francisco, USA. http://researcharchive.calacademy.org/research/ 
ichthyology/ catalog/fishcatmain.asp [Accessed on 28 February 2017.]

Freitas M., Almeida A.J., Delgado J., González J.A., Santana J.I., Biscoito M. 2011. First record of Hydrolagus affinis (Holocephali: Chimaeriformes: Chimaeridae) from Madeira and the Seine Seamount (North Atlantic Ocean). Acta Ichthyologica et Piscatoria 41 (3): 255-257.

DOI: 10.3750/AIP2011.41.3.14

González J.A., Ben Cherifi S., Lozano I.J., Manchih K., Jiménez S., Elouamari N., Pérez-Peñalvo J.A, García-Mederos A., Domínguez-Seoane R., Santana J.I., Biscoito M. 2014. Scientific results of the Spanish-Moroccan RAI-AP-36/2005 and RAIAP-37/2005 deep-sea campaigns off NW Africa $\left(33^{\circ} \mathrm{N}-\right.$ $26^{\circ} \mathrm{N}$, Northeastern Atlantic). General description and list of stations. Boletim do Museu de História Natural do Funchal 64 (337): 5-27.

González J.A., Biscoito M. 2015. First record of the deep-sea stomatopod Bathysquilla microps (Manning, 1961) (Stomatopoda, Bathysquillidae) from the eastern Atlantic Ocean. Crustaceana 88 (12-14): 1301-1306. DOI: $10.1163 / 15685403-00003495$

Holt R.E., Foggo A., Neat F.C., Howell K.L. 2013. Distribution patterns and sexual segregation in chimaeras: Implications for conservation and management. ICES Journal of Marine Science 70 (6): 1198-1205.

DOI: $10.1093 /$ icesjms/fst058

Luchetti E.A., Iglésias S.P., Sellos D.Y. 2011. Chimaera opalescens n. sp., a new chimaeroid (Chondrichthyes: Holocephali) from the north-eastern Atlantic Ocean. Journal of Fish Biology 79 (2): 399-417. DOI: $10.1111 / \mathrm{j} .1095-8649.2011 .03027 . x$
Maul G. 1949. Lista sistemática dos peixes assinalados nos mares da Madeira e índice alfabético. [Systematic list of fish reported in the Madeira and alphabetical index.] Pp. 135-159. In: Noronha A.C., Sarmento A.A. (eds.) Vertebrados da Madeira, $2^{\circ}$ Volume Peixes. [Vertebrates of Madeira, Volume 2 - Fishes.] Junta Geral do Distrito Autónomo do Funchal, Funchal, Portugal.

Møller P.E., Kullberg T., Jørgensen O.A. 2004. New records of chimaeroid fishes from Greenland waters (North Atlantic), with description of juvenile Chimaera monstrosa and Hydrolagus affinis (Holocephali, Chimaeridae). Cybium 28 (1): 55-60.

Pajuelo J.G., Seoane J., Biscoito M., Freitas M., González J.A. 2016. Assemblages of deep-sea fishes on the middle slope off Northwest Africa $\left(26^{\circ}-33^{\circ} \mathrm{N}\right.$, eastern Atlantic). Deep Sea Research Part I: Oceanographic Research Papers 118: 66-83.

DOI: 10.1016/j.dsr.2016.10.011

Vieira R.P., Cunha M.R. 2014. In situ observation of chimaerid species in the Gorringe Bank: New distribution records for the north-east Atlantic Ocean. Journal of Fish Biology 85 (3): 927-932. DOI: $10.1111 /$ jfb. 12444

Weigmann S. 2016. Annotated checklist of the living sharks, batoids and chimaeras (Chondrichthyes) of the world, with a focus on biogeographical diversity. Journal of Fish Biology 88 (3): 837-1037. DOI: $10.1111 / \mathrm{jfb} .12874$

Received: 11 September 2016 Accepted: 30 January 2017 Published electronically: 31 March 2017 